\title{
FAKTOR-FAKTOR YANG MEMPENGARUHI NILAI UJIAN KETERAMPILAN KLINIK DASAR MODUL GASTROINTESTINAL PADA MAHASISWA PROGRAM STUDI PENDIDIKAN DOKTER ANGKATAN 2008
}

\section{Oleh : Arif Wicaksono ${ }^{1}$}

\begin{abstract}
Abstrak
Latar belakang. Visi menghasilkan sarjana dan profesional kedokteran yang berkualitas tinggi dan kompetitif di tingkat regional, nasional dan internasional untuk mewujudkan Kalimantan Barat sehat pada tahun 2020 merupakan hal yang cukup menantang bagi PSPD FK Untan. Salah satu kompetensi yang harus dimiliki adalah keterampilan klinik dasar yang dapat menjadi bekal penting pada para mahasiswa. Tujuan. Penelitian ini mencari hubungan antara faktor-faktor yang dicurigai berpengaruh terhadap nilai ujian keterampilan klinik dasar nodul gastrointestinal pada mahasiswa PSPD angkatan 2008. Metode. Penelitian ini merupakan penelitian analitik cross sectional dengan instrumen kuesioner. Uji yang digunakan adalah uji korelasi dan regresi berganda. Hasil. Sebanyak 69 mahasiswa mengikuti penelitian ini. Tidak terdapat hubungan bermakna antara faktor materi dan nilai ujian $\operatorname{KKD}(p=0,136)$, tidak terdapat hubungan bermakna antara faktor penunjang dan nilai ujian $\operatorname{KKD}(\mathrm{p}=0,465)$, tidak terdapat hubungan bermakna antara faktor mahasiswa dan nilai ujian $\mathrm{KKD}(\mathrm{p}=0,087)$ serta tidak ada hubungan bermakna diantara faktor materi, penunjang dan mahasiswa terhadap nilai ujian $\mathrm{KKD}(\mathrm{p}>0,05)$.
\end{abstract}

Kata kunci : profesional, kompetensi, keterampilan klinik dasar, modul gastrointestinal

\section{PENDAHULUAN}

Pendidikan kedokteran di Program Studi Pendidikan Dokter(PSPD) Fakultas Kedokteran (FK) Universitas Tanjungpura(Untan) memiliki visi menghasilkan sarjana dan profesional kedokteran yang berkualitas tinggi dan kompetitif di tingkat regional, nasional dan internasional untuk mewujudkan Kalimantan Barat sehat pada tahun 2020 (BPA FK Untan, 2011). Kurikulum PSPD menekankan pada tujuh kompetensi yang sesuai dengan kurikulum nasional yaitu :

${ }^{1}$ Arif Wicaksono : Dosen Jurusan Pendidikan Kedokteran Untan 
1. Keterampilan komunikasi efektif

2. Keterampilan klinik dasar

3. Keterampilan menerapkan dasar-dasar ilmu biomedis, perilaku, klinis dan epidemiologi pada kedokteran keluarga

4. Keterampilan pengelolaan masalah kesehatan pada individu, keluarga maupun masyarakat dengan cara yang komprehensif, holistik, berkesinambungan,terkoodinir dan bekerjasama dalam konteks pelayanan kesehatan primer

5. Memanfaatkan dan menilai secara kritis teknologi informasi

6. Mawas diri dan pengembangan diri dengan belajar sepanjang hayat

7. Etika, moral dan profesionalisme dalam praktek (BPA FK Untan,2011).

Penelitian ini akan menitikberatkan pada kompetensi kedua yaitu kompetensi keterampilan klinik dasar pada mahasiswa PSPD FK Untan angkatan 2008.

\section{TINJAUAN PUSTAKA}

\section{Ketrampilan Klinik Dasar}

Ketrampilan Klinik Dasar (KKD) merupakan keterampilan yang harus dimiliki oleh dokter umum, diajarkan dan dipelajari sebagai bekal untuk memeriksa pasien pada masa kepaniteraan (magang di Rumah Sakit) dan pada akhirnya sebagai bekal memeriksa pasien saat praktek mandiri yang sebenarnya, dikenal juga sebagai keterampilan medik atau skill's lab (BPKM FK UII, 2007)

Pembelajaran KKD melibatkan tenaga pengajar, pembimbing KKD dan sarana penunjang lain seperti ruangan yang disiapkan secara khusus, alatalat simulasi/manekin, media audiovisual maupun pasien, baik pasien sebenarnya maupun pasien simulasi yang disiapkan untuk kasus-kasus tertentu(BPKKD FK Untan, 2011).

\section{Modul Gastrointestinal}

Modul merupakan kegiatan program belajar-mengajar yang dapat dipelajari oleh siswa dengan bantuan yang minimal dari pembimbing, meliputi perencanaan tujuan yg akan dicapai secara jelas, penyediaan materi pelajaran, alat yg dibutuhkan, serta alat untuk penilai, mengukur keberhasilan siswa dalam penyelesaian pelajaran(KBBI, 2008)

PSPD FK Untan menggunakan modul dalam pembelajarannya sedangkan pada FK lain biasa disebut dengan blok/paket. Modul gastrointestinal merupakan modul di semester empat/ tahun ke dua pendidikan dokter. Modul ini dipilih karena berada ditengah-tengah tahap 
pendidikan sehingga mahasiswa sudah familiar dengan KKD dan terdapat banyak materi KKD yang diajarkan dan diujikan.

Mahasiswa angkatan 2008 terpilih sebagai subjek penelitian karena modul gastrointestinal diikuti oleh sebagian besar mahasiswa angkatan 2008, dan sebaran subjek penelitian pada mahasiswa tersebut cukup homogen.

Modul gastrointestinal mempelajari tentang sistem pencernaan pada manusia. Pada modul ini diharapkan mahasiswa dapat mempelajari teori, keterampilan klinik sampai diagnosis dan penatalaksanaan dari pasien dengan keluhan sistem pencernaan (BRP MGI, 2010).

KKD pada modul gastrointestinal mencakup :

1. Memperoleh riwayat penyakit yang lengkap dan akurat serta melakukan pemeriksaan komprehensif pada berbagai keadaan pasien yang dihadapi dengan cara :

a. Melakukan anamnesis lengkap pada orang dewasa

b. Melakukan alloanamnesis/anamnesis lengkap pada anak sesuai dengan usia dan tahap perkembangan

c. Melakukan anamnesis yang dapat menggali etiologi/ patogenesis/ patofisiologi penyakit

d. Memanfaatkan sumber informasi sekunder dalam mengelola pasien.

2. Melakukan pemeriksaan fisik lengkap meliputi keadaan umum, tanda vital, denyut nadi, frekuensi pernapasan, suhu badan, tekanan darah dan keadaan kulit.

a. Melakukan pemeriksaan abdomen, genitalia eksterna, pelvis, rektum

b. Melakukan pemeriksaan fisik anak dan neonatus

c. Melakukan pemeriksaan kasus emergensi

d. Memilih pemeriksaan khusus yang sesuai dengan diagnosis kerja berdasarkan keluhan pasien, kepentingan pasien, urgensi, dan kompleksitas masalah.

3. Prosedur Klinik Medik dan Bedah

a. Melakukan tindakan pencegahan universal dan penanganan bahantercemar/terinfeksi

b. Melakukan kerja dengan teknik steril

c. Melakukan suntikan: intradermal, subkutan, intramuskular, dan intravena.

d. Melakukan pemasangan pipa nasogastrik 
4. Memilih dan melaksanakan secara profesional, berbagai prosedur klinik dan laboratorium serta menafsirkan hasilnya secara akurat yaitu melakukan analisis tinja (BPPKM FK UI,2009).

KKD yang telah dipelajari kemudian diujiankan dengan penilaian

\begin{tabular}{|c|c|}
\hline Nilai Angka & Nilai Huruf \\
\hline $80-100$ & A \\
\hline $70-79$ & B \\
\hline $60-69$ & C \\
\hline $50-59$ & D \\
\hline$<50$ & E \\
\hline
\end{tabular}

\section{Faktor-faktor yang mempengaruhi nilai ujian}

Pada penelitian ini terdapat tiga faktor yang dicermati yaitu:

1. Faktor materi

2. Faktor penunjang

3. Faktor mahasiswa

Faktor materi memperhatikan jenis materi yang diberikan, kejelasan penyampaian materi oleh narasumber, apakah materi yang diberikan sesuai dan apakah materi mudah/susah dilakukan.

Faktor penunjang adalah fasilitas dan infrastruktur yang ada untuk menunjang KKD seperti ruangan, daftar tilik, alat-alat KKD, apakah alat KKD mencukupi, apakah setiap mahasiswa dapat melakukan KKD, apakah mahasiswa diberi atau mendapat kesempatan melakukan KKD dan waktu apakah mencukupi baik saat pelaksanaan KKD maupun ujian KKD.

Faktor mahasiswa melihat kesiapan dari mahasiswa dalam menghadapi KKD seperti kesiapan materi atau kecemasan saat akan ujian KKD dan halhal yang menyebabkan kecemasan pada mahasiswa.

\section{METODOLOGI}

Penelitian ini merupakan penelitian analitik cross sectional yang dilakukan selama bulan Maret 2010 di PSPD FK Untan

Sampel dalam penelitian ini adalah sebanyak 69 orang yang memenuhi kriteria penelitian sebagai berikut :

Kriteria Inklusi

1. Masuk ke PSPD FKIK UNTAN pada tahun 2008

2. Sedang mengikuti modul gastrointestinal

Kriteria Eksklusi

1. Tidak bersedia ikut dalam penelitian

2. Tidak melengkapi data pada kuesioner 
Variabel penelitian pada penelitian ini adalah faktor materi, faktor penunjang dan faktor mahasiswa sebagai variabel bebas dan nilai ujian KKD sebagai variabel terikat.

Instrumen yang digunakan pada penelitian ini adalah kuesioner yang berisi pertanyaan mengenai faktor materi, faktor penunjang dan faktor mahasiswa, diberi skor untuk masing-masing item pertanyaan dan dirata-rata untuk masing faktor.

Analisis data dilakukan menggunakan SPSS 17 yang terbagi menjadi analisis univariat, bivariat dan multivariat. Analisis univariat dilakukan untuk melihat frekwensi, analisis bivariat digunakan untuk melihat kekuatan hubungan dan signifikansi hubungan menggunakan korelasi Spearman dan analisis multivariat untuk melihat pengaruh antar variabel bebas terhadap varibel terikat menggunakan regresi berganda.

\section{HASIL}

Pembagian kuesioner dilakukan beberapa saat setelah mahasiswa selesai menjalani ujian KKD. Mahasiswa diberikan penjelasan singkat mengenai kesediaan mengisi kuesioner, etika penelitian dan cara mengisi kuesioner. Mahasiswa diberikan waktu 30 menit untuk menjawab item-item pertanyaan dalam kuesioner dan langsung dikumpulkan pada peneliti.

Jumlah mahasiswa PSPD FK Untan angkatan 2008 adalah 81 orang sedangkan subjek penelitian berjumlah 69 orang. Hal ini dikarenakan pada saat ujian ada mahasiswa yang tidak mengambil modul gastrointestinal(mengambil/mengulang modul lain) sakit, berhalangan dan ada yang tidak melengkapai data pada kuesioner sehingga dieksklusikan dari penelitian.

\section{Analisis univariat}

Subjek penelitian laki-laki sebanyak 33 orang $(47,83 \%)$ dan perempuan sebanyak 36 orang $(52,17 \%)$. Subjek penelitian berasal dari ikatan dinas sebanyak 44 orang $(63,8 \%)$, SNMPTN sebanyak 9 orang (13 $\%$ ) dan Jalur mandiri berbakat sebanyak 16 orang( 23,2 \%).

Faktor materi

Subjek penelitian menyatakan faktor materi sangat kurang sebanyak dua orang $(2,9 \%)$, kurang sebanyak 49 orang (71\%) dan baik sebanyak 18 orang $(26,1 \%)$. 


\section{Faktor pendukung}

Subjek penelitian menyatakan faktor pendukung sangat kurang sebanyak tujuh orang $(10,1 \%)$, kurang sebanyak 26 orang $(37,8 \%)$, baik sebanyak 35 orang $(50,7 \%)$ dan sangat baik sebanyak satu orang $(1,4 \%)$.

\section{Faktor mahasiswa}

Subjek penelitian menyatakan sedikit cemas sebanyak empat orang $(5,8 \%)$, cemas sebanyak 38 orang $(55,1 \%)$ dan sangat cemas sebanyak 27 orang $(39,1 \%)$.

Nilai ujian KKD

Nilai ujian KKD 50-59 sebanyak 13 orang(18,9 \%), 60-69 sebanyak 39 orang $(56,5 \%), 70-79$ sebanyak 16 orang $(23,2 \%)$ dan $80-100$ sebanyak satu orang $(1,4 \%)$.

\section{Analisis bivariat}

Hubungan antara faktor materi dan nilai ujian KKD tidak bermakna ( $\mathrm{p}$ $=0,136)$ dengan kekuatan hubungan rendah $(0,134)$. Hal ini menunjukkan tidak ada hubungan bermakna antara memperhatikan jenis materi yang diberikan, kejelasan penyampaian materi oleh narasumber, apakah materi yang diberikan sesuai dan apakah materi mudah/susah dilakukan dan nilai ujian KKD pada penelitian ini.

Hubungan antara faktor penunjang dan nilai ujian KKD tidak bermakna $(p=0,465)$ dengan kekuatan hubungan sangat rendah $(0,011)$. Hal ini menunjukkan tidak ada hubungan bermakna antara ruangan, daftar tilik, alat-alat KKD, apakah alat KKD mencukupi, apakah setiap mahasiswa dapat melakukan KKD, apakah mahasiswa diberi atau mendapat kesempatan melakukan KKD dan waktu apakah mencukupi baik saat pelaksanaan KKD maupun ujian KKD dan nilai ujian KKD pada penelitian ini.

Hubungan antara faktor mahasiswa dan nilai ujian KKD tidak bermakna $(\mathrm{p}=0,087)$ dengan kekuatan hubungan rendah $(0,166)$. Hal ini menunjukkan tidak ada hubungan bermakna antara kesiapan materi atau kecemasan saat akan ujian KKD dan nilai ujian KKD pada penelitian ini.

\section{Analisis Multivariat}

Pada penelitian univariat memberikan hasil $p>0,05$ yang berarti tidak ada hubungan yang bermakna antara faktor materi, faktor penunjang dan faktor mahasiswa terhadap nilai ujian KKD pada penelitian ini.

\section{PEMBAHASAN}

Hasil penelitian menunjukkan tidak ada hubungan bermakna antara variabel bebas dan variabel terikat. Pertanyaan yang muncul adalah apakah 
benar tidak ada hubungan antara faktor-faktor yang dicermati dan nilai ujian KKD? Pada penelitian ini jawabannya adalah ya.

Penyebab dari tidak adanya hubungan bermakna kemungkinan besar karena nilai ujian KKD sebagian besar pada kisaran menengah yaitu 60-79 sebanyak 55 orang $(79,7 \%)$. Angka ini memperlihatkan tingkat penguasaan materi yang cukup dan tidak ada nilai ekstrim pada kelompok lain sehingga apapun keluhan atau pendapat atau pernyataan dari subjek penelitian terkait faktor-faktor yang mempengaruhi nilai ujian KKD tidak dapat menciptakan hubungan yang bermakna terhadap nilai ujian KKD tersebut.

Nilai ujian KKD didapatkan dari rata-rata nilai dari beberapa station/pos pengujian dengan kasus-kasus tertentu. Apakah soal sudah baik/representatif? Apakah waktu untuk mengerjakan soal mencukupi? Apakah mahasiswa memang sudah benar-benar siap ujian? Bagaimana mahasiswa mempersiapkan diri mereka? Apakah penguji sudah tersandarisasi? Apakah penilaian sudah objektif?

Soal-soal yang dikeluarkan pada saat ujian dikumpulkan dari beberapa narasumber, ditelaah dan diperbaiki sebelum diujiankan. Soal yang diujiankan terdapat beberapa tipe soal dan kasus sehingga dapat bervariasi dan memperkaya soal dan modul itu sendiri.

Waktu untuk mengerjakan soal bervariasi setiap modul. Waktu yang disepakati terlebih dahulu diuji cobakan apakah sudah sesuai untuk mengerjakan soal untuk kandidat S1. Setiap beberapa pos pengujian diberikan istirahat guna keperluan istirahat dan presensi.

Persiapan mahasiswa sangat bervariasi. Pihak fakultas memberikan kesempatan melakukan KKD beberapa kali dengan review, mahasiswa juga ada yang membentuk kelompok-kelompok kecil di luar waktu belajar mengajar baik sendiri, dengan bantuan pembimbing KKD maupun bantuan dari kakak kelas mereka. Berbagi pengalaman antara senior dan junior memungkinkan interaksi positif yang saling membangun dan kemungkinan besar membantu persiapan ujian KKD mahasiswa.

Penguji ujian KKD melakukan rapat dan persiapan bersama-sam sehingga satu pendapat mengenai suatu kasus sehingga dengan penguji manapun, hasil yang didapatkan akan sama. Penguji juga memiliki kode etik sendiri, profesional dan selalu objektif dalam menilai mahasiswa.

Pernyataan mahasiswa pada kuesioner banyak yang menyatakan kurangnya faktor materi dan faktor penunjang. Banyak yang menyatakan kurangnya waktu KKD karena alat yang sedikit harus digunakan oleh mahasiswa yang banyak sehingga ada yang mendapat kesempatan, ada yang hanya melihat temannya mengerjakan dan bahkan ada yang tidak melakukan apa-apa saat KKD. Hal ini merupakan sesuatu yang harus diperhatikan 
fakultas untuk menciptakan suasana yang lebih kondusif, baik dengan memperbanyak alat dan ruangan KKD, memeberikan waktu yang lebih banyak atau membagi lagi kelompok KKD ke kelompok yang lebih kecil lagi sehingga tiap mahasiswa dapat melakukan KKD dengan baik.

Materi KKD diberikan oleh narasumber yaitu dokter spesialis dan dokter umum yang kompeten di bidang KKD tertentu. Mahasiswa yang merasa masih kurang materinya kita gerakkan untuk lebih aktif mencari literatur yang baik dan mengkonfirmasi ulang pada narasumber yang bersangkutan mengenai hasil yang didapatkan. Hal ini akan menunjang cara belajar mahasiswa aktif yang sesaui dengan pembelajaran berdasarkan masalah(problem based learning) dan pembelajaran berdasarkan bukti (evidence based learning) yang kita bekalkan pada mahasiswa PSPD FK Untan.

Kecemasan dialami oleh semua mahasiswa dengan tingkatan yang berbeda. Kecemasan perlu diuji dengan standar tertentu untuk menentukan kecemasan tersebut fisiologis atau patologis. Kecemasan yang dialami dimungkinkan oleh banyak faktor seperti kesiapan mahasiswa, kemungkinan soal yang akan keluar saat ujian, penguji ujian maupun waktu yang diberikan saat ujian sampai keinginan atau tuntunan untuk mendapatkan nilai yang baik. Seiring dengan berjalannya waktu, mahasiswa akan mempunyai copemechanism dalam menghadapi situasi seperti ini. Dokter nantinya akan dihadapkan dengan pasien-pasien secara terus menerus dengan berbagai kasus yang ada. Kecemasan bisa timbul, tetapi harus dihadapi sehingga dapat melayani masyarakat dengan baik dan profesional.

\section{DAFTAR RUJUKAN}

Pusat Bahasa. Kamus Besar Bahasa Indonesia. Edisi ke-4. Departemen pendidikan Nasional. Jakarta

Sarwono, J. 2009. Statistik itu Mudah. ANDI. Yogyakarta.

Sugiyono. 2005. Statistika untuk Penelitian.Alfabeta. Bandung.

Tim Kepaniteraan. 2009. Buku Pedoman Praktik Klinik Mahasiswa FK UI. FK UI. Jakarta

Tim KKD. 2011. Buku Panduan Keterampilan Klinik Dasar. FK UNTAN. Pontianak

Tim Modul. 2010. Buku Rancangan Pengajaran Modul Gastrointestinal. FK UI. Jakarta

Tim Penyusun . 2011. Buku Panduan Akademik. FK UNTAN. Pontianak

Tim Penyusun. 2007. Buku Panduan Keterampilan Medik. FK UII. Yogyakarta 